\title{
Perceived effects of climate change on profit efficiency among small scale chili pepper marketers in Benue State, Nigeria
}

\author{
Djomo Choumbou Raoul Fani - Henrietta Udeme Ukpe • Ngo Valery Ngo (i) \\ Sani Mohamadou $\cdot$ Miranda Adedze $\cdot$ Ngambouk Vitalis Pemunta $(\mathbb{D}$
}

Published online: 20 February 2020

(C) The Author(s) 2020

\begin{abstract}
In the determination of the level of efficiency of an enterprise, the role of climate change cannot be overemphasized. However, some scholars are of the view that climate change might not really affect the level of efficiency of an enterprise due to its indirect effect on the performance of an enterprise. Understanding the perception of marketers of agricultural produce about climate change in agribusiness is paramount to sustain small scale enterprises. This study sought to analyze the perceived effects of climate change on profit efficiency among small scale chili pepper marketers in Benue State, Nigeria. Data
\end{abstract}

C. R. F. Djomo · S. Mohamadou

Department of Agricultural Economics, Federal

University of Agriculture, Makurdi, P. M. B 2373,

Makurdi, Benue State, Nigeria

H. U. Ukpe

Department of Agricultural Economics and Extension, Federal University Wukari, Taraba State, P. M. B 1020

Wukari, Taraba State, Nigeria

N. V. Ngo - M. Adedze

Department of Global Health, School of Public Health and Community Medicine, Institute of Medicine, Sahlgrenska Academy, University of Gothenburg, Gothenburg,

Sweden

N. V. Pemunta $(\bowtie)$

School of Public Health and Community Medicine, Institute of Medicine, Sahlgrenska Academy, University of Gothenburg, Gothenburg, Sweden

e-mail: vitalis.pemunta@gu.se;

vitalispemunta@gmail.com were collected with the use of structured questionnaire and analyzed using stochastic frontier production function. A combination of purposive and random sampling techniques was used to select 349 producers and marketers, 152 processors, 143 processed retailers and 145 non-processed retailers giving a total of 789 small scale chili pepper marketers from three (3) agricultural zones that make up Benue State, Nigeria. The result showed that on the average, small scale chili pepper marketers are relatively profit efficient. The results also showed that in the marketing chain, small scale processed retailers had the highest mean profit efficiency (0.86). It was therefore recommended that switching business to adapt to crop varieties (cereal crops) that are more resilient to climate change could be an opportunity to small scale chili pepper marketers struggling with chili pepper to leapfrog previous performance and become more productive. Further, the training on preservation of perishable crop should be given to chili pepper producers and marketers and non-processed retailers given that excessive rainfall decreases their profit efficiency.

Keywords Drought - Rainfall · Temperature · Profit efficiency and transportation

\section{Introduction}

Agriculture in developing countries is becoming more commercially oriented as many villages are 
getting connected to the urban and the oversea markets (Wiggins et al. 2011). It has necessitated even small-scale farmers to produce in surplus for commercialization. Thus, there is a growing need to identify and improve the production of commodities that have international market potentials. In Nigeria, such produce includes chili pepper (Suleiman and Isah 2010). Also, for a country to attain growth and development, the economy has to be diversified. That is, there should be a simultaneous development of various sectors of the economy instead of overreliance on a particular sector of the economy (mono production-based economy). In Nigeria, almost all other sectors of the economy seem to have gone into oblivion, thereby, making the country to depend almost entirely on crude oil for her foreign exchange (Ocheni 2015). In this respect, the expansion of export-base commodities is of tremendous importance to the overall development of the economy (Awe and Ajayi 2009; Bala 2015). Climate change has an impact on market systems that typically involve the provision and sale of goods and services in formal and informal markets (IPCC 2007a, b; Barrueto et al. 2017). The effects and impact of climate change depend strongly on the market system and the regional context (Mendelsohn et al. 2000; Barrueto et al. 2017). Out of all market systems, natural resource-based market systems, especially the agricultural systems, by extension, food security, are highly vulnerable to the different impacts of climate change (Mendelsohn et al. 2000; Barrueto et al. 2017; Lobell et al. 2008). Extreme climatic changes are not exclusively influencing the agricultural sector: they are also increasingly affecting other sectors such as the manufacturing and the transport sectors, leading to broader socio-economic challenges (Berkhout et al. 2002; Barrueto et al. 2017).

Climate change is one of the life-threatening environmental phenomena that affect economic development and sustainability worldwide (Adefolalu 2007; Ikhile 2007; Nwalem 2015). The natural climate cycle and human activities have contributed to an increase in the accumulation of heat-trapping "greenhouse" gases in the atmosphere, causing temperature increase globally (global warming) (United Nations Framework Convention on Climate Change (UNFCCC) 2007; Nwalem 2015). Available evidence shows that Nigeria is already facing what looks like a plague with diverse ecological problems directly linked to the on-going climate change (Adefolalu 2007; Enete and Amusa 2010; Ikhile 2007; Nwalem 2015). Around the 18th century, the average temperature in Nigeria was around 26.74 Celsius. However, the temperatures reached an all-time high of 31.83 Celsius in April of 2010 (https//:tradingeconomics.com). The rain forest zone of Nigeria, which is mostly known for high rainfall, is currently confronted by irregularities in rainfall patterns, while the Guinea savannah is experiencing a gradual increase in temperature. The Sahel savannah zone faces the threat of desert encroachment at a high-speed per year occasioned by the fast reduction in the amount of surface water, flora, and fauna (Federal Ministry of Environment 2004; Obioha 2008; Nwalem 2015). In a study conducted by Nwalem et al. (2019) in Benue State, Nigeria, climate change have caused a shift in the timing of rainfall, drought, extreme temperatures, floods, excess rain, nutrient leaching, soil erosion, pest and disease infestation.

Pepper is an important agricultural crop not only because of its economic importance but also due to the nutritional and medicinal value of its fruits as well as being an excellent source of natural colors and antioxidant compounds (Howard et al. 2000). It is the world's second important vegetable, ranking after tomatoes, and it is the most produced type of spices, flavoring, and coloring for food while providing essential vitamins and minerals. The nutritional value of pepper merits special attention. It is a rich source of vitamins $\mathrm{A}$ and $\mathrm{E}$. Both hot and sweet peppers contain more vitamin $\mathrm{C}$ that contributes to building a healthy body immunity to be able to prevent individuals from cold and flu than any other vegetable crop (Bosland and Votava 2000). Several factors affect the production and productivity of crops, among which climate change is the primary determinant of crop productivity, and it influences yield, hydrologic balances, input, supplies, and other components of agricultural systems. Fourth International panel on climate change (IPCC) strongly highlighted the global and regional impacts of climate change primarily on agriculture, water resources, natural eco-systems, and nutritional food security (IPCC 2007a, b; Bhutia et al. 2018). Changes in climatic factors such as temperature, precipitation and the frequency and severity of extreme events like drought, floods, and windstorms directly affect the crop yields (Sarada et al. 2015; Bhutia et al. 2018). 
One of the adverse effects of climate change is global warming that has led to a rise in global temperature due to the generation and accumulation of greenhouse gases. Crops growth is influenced by heat due to the balance between photosynthesis and respiration (Yanez-Lopez et al. 2012; Bhutia et al. 2018). High temperatures affect many aspects of plant physiology and growth, which in turn may have a direct or indirect effect on crop yield (Erickson and Markhart 2001; Bhutia et al. 2018). Many studies have shown the direct impact of increased or decreased temperature in the production of chili pepper (Garruna-Hernandez et al. 2014; Bhutia et al. 2018). Pepper that is grown under high temperature $\left(33^{\circ} \mathrm{C}\right.$ ) shows reduced fruit set (Yanez-Lopez et al. 2012; Bhutia et al. 2018), and flower malformation when grown in temperatures below $18^{\circ} \mathrm{C}$ resulting in the formation of parthenocarpic fruits and reduced fruit set (Aloni et al. 1999; Bhutia et al. 2018). An increase in global temperatures due to climate change has altered the timing and amount of rainfall and availability of water leading to the frequent occurrence of weather extremes such as drought and floods (Ayyogari et al. 2014; Bhutia et al. 2018). The drought condition adversely affects the germination of seeds and also has other adverse effects on crop growth and development (Ayyogari et al. 2014; Bhutia et al. 2018). Due to the limited availability of water for irrigation, the cultivation of crops is only possible in $16 \%$ of the potential arable area (Alexandratos and Bruinsma 2012; Bhutia et al. 2018). The occurrence of drought increases the concentration of salts in the soil, leading to reverse osmosis and causing the loss of water from plant cells. Plant cells become dehydrated, leading to poor growth and low productivity as a result of the inhibition of several physiological and biochemical processes such as photosynthesis and respiration, etc. (Pena and Hughes 2007; Bhutia et al. 2018).

Chilli pepper (Capsicum frutescens) is a highvalue crop that is grown for cash by farmers all over the world (Aliyu et al. 2012). Nigeria is known to be one of the significant producers of pepper in the world accounting for about $50 \%$ of the African production (Idowu-agida et al. 2010). Agriculture in Nigeria is dominated by small-scale farmers who produced the bulk of the food consumed in the country (Asogwa et al. 2006). Although these peasant farmers occupy a unique and pivotal position, they belong in the most deprived group of the population and, as such, cannot invest much on their farms (Asogwa et al. 2006; Bala 2015). Computing profit efficiency, therefore, constitutes a more important source of information for policymakers than the partial vision offered by analyzing cost efficiency (Maudus et al. 2003; Ogundari 2006). This research provides empirical evidence on the perception of different market participants in the chili pepper enterprise regarding the effect of climate change. It will help policymakers to plan and institute adequate measure to protect small scale entrepreneurs. This study also contributes to knowledge with the inclusion of climatic variables in the stochastic profit function (SPF) model, which will serve as a guide for further research. Several studies (Aiello and Bonanno 2013; Tronga and Napasintuwongb 2015; Hoang and Yabe 2012; Oladeebo and Oluwaranti 2012; Ali and Flinn 1989; Kolawole 2006) have been done to estimate profit efficiency as well as linking climate change with agricultural production (Karki and Gurung 2012; Ranjitkar et al. 2016; Maharjan and Joshi 2013; Avnery et al. 2011) with little or no emphasis on the linkage between climate change and chili pepper marketing. It is against this backdrop that this study intends to fill the research gap by analyzing the perceived effects of climate change on profit efficiency among small scale chili pepper marketers in Benue State, Nigeria

\section{Theoretical framework}

This study analyses the perceived effects of climate change on profit efficiency among small scale chili pepper marketers in Benue State, Nigeria. The analysis will be informed by the theory of efficiency using the Stochastic Frontier profit framework (SFPF). The stochastic frontier analysis (SFA) is a stochastic method because it allows individuals to be distant from the frontier and for randomness (Aigner et al. 1977; Meeusen and van de Broek 1997; Aiello and Bonanno 2013; Djomo 2019). It differs from the Data Envelopment Analysis (DEA), which supposes that distance from the frontier is entirely due to inefficiency. Again, SFA assigns a distribution to the stochastic component of the model and, thus, allows us to make inferences (Simar and Wilson 2000; Aiello and Bonanno 2013; Djomo 2019). Another 
advantage of SFA is that it improves the consistency of the previous modeling where one will first estimate inefficiency using a frontier and then use the estimated efficiency-score as the dependent variable in subsequent regression (Greene 1993; Battese and Coelli 1995; Aiello and Bonanno 2013; Djomo 2019). As shown by Lensink and Meesters (2012), and Wang and Schimdt (2002), the two-step approach suffers from the fact that the inefficiency is assumed to be identically and independently distributed in the central frontier equation, while it depends on other variables in the inefficiency equation (Aiello and Bonanno 2013; Djomo 2019). Another drawback of the SFA is that it imposes a functional form (and hence all its associated behavioral assumptions), which predetermines the shape of the frontier. If the functional form is not specified, the estimated efficiency may be confounded with significant bias.

Following Aiello and Bonanno (2013), and Djomo (2019), the profit function $F p($.$) states the profit$ obtainable from producing y at input price.

Profit $_{i t}=F_{P}(y, w) e^{y p} e^{-u p}$

Equation (1) is an alternative profit function since it depends on inputs and outputs, whereas the actual profits depend on the prices of production. It uses the same variables like the cost function, implying that output-prices are free to vary (Huizinga et al. 2001; Aiello and Bonanno 2013; Djomo 2019). Similarly, the profit efficiency of chili pepper marketers is the ratio between the observed respondent's (producer and marketers, processors, processed retailers, and non-processed retailers) profit and the maximum level of profit achievable in case of full efficiency (Aiello and Bonanno 2013; Djomo 2019).

$P E=\frac{F_{P}(w, y) e^{v p} e^{-u p}}{F_{P}(y, w) e^{v p}}=e^{-u p}$

\section{Empirical review}

Tronga and Napasintuwongb (2015) analyzed profit inefficiency among hybrid rice farmers in Central Vietnam using the SFA method with a stochastic translog normalized profit frontier function. The results showed that the average profit efficiency was 0.63 , implying 0.37 was profit inefficient. Aiello and
Bonanno (2013) evaluated the cost and the profit efficiency of the Italian banking sector over the period 2006-2011 using translog stochastic frontiers. Results showed that the average levels of cost and profit efficiency were both around $90 \%$ and that they were quite stable over time. However, there is high heterogeneity in results. Differences exist when banks are ranked by size (efficiency tends to decrease with size), legal type (cooperatives perform better than others), and area (the best performers are in the northeast of the country).

Hoang and Yabe (2012) estimated the impacts of environmental factors on the profit efficiency of rice farmers in the Red River Delta of Vietnam using both Ordinary Least Square (OLS) and Maximum Likelihood Estimation (MLE) translog profit functions. They found that the profit efficiency was about $75 \%$ on average and that environmental factors besides farm-specific characteristics changed profit efficiency significantly. Oladeebo and Oluwaranti (2012) used the explicit Cobb-Douglas functional form of the SFPF to examine the profit efficiency in cassava production to isolate significant factors leading to variation in farm-specific profit inefficiencies among cassava producers. The result of the analysis showed that the profit efficiencies of the farmers ranged between 20 and $91 \%$. In contrast, the mean level of profit efficiency was $79 \%$, which suggested that an estimated $21 \%$ loss in profit was due to a combination of both technical and allocative inefficiencies. Ali and Flinn (1989) estimated the profit efficiency by comparing the OLS and MLE approaches to show the profitability of rice production in Pakistan.

Kolawole (2006) estimated the profit function by adding a constant to profit function to obtain the positive values and used the Cobb-Douglass function to estimate profit frontier. Rahman (2003) provided a direct measure of the production efficiency of the Bangladeshi rice farmers using a translog SFPF and inefficiency effects model. The results showed that there are high levels of inefficiency in modern rice cultivation with a mean level of profit efficiency of 77\%. Adesina and Djato (1996) analyzed the relative efficiency of women as farm managers in Cote d'Ivoire using the restricted normalized profit function method. They found that the relative degree of efficiency of women is like that of men. 


\section{Methodology}

The study area

This study was conducted in Benue State, one of the 36 states in Nigeria. Nigeria is a sub-Sahara African country and is located in the western part of the continent. It is the most populous country in Africa, and the most populated black nation on earth (Akpotor and Agbebaku 2010). Nigeria has a varied climate ranging from tropical areas on the coast to the arid zone in the North. This gives the country a unique opportunity to produce that can be grown in both the tropical and semi-tropical regions of the world (Olayemi et al. 2012). Benue state, located in the middle belt of Nigeria, derives its name from River Benue, the second-largest river in Nigeria. The State was created in 1976 with 23 local government areas. According to the 2006 census, Benue State is estimated to have a population of about $4,253,641$ inhabitants and a land size of about $33,955 \mathrm{~km} 2$ (Akaakohol and Aye 2014). The average population density is 99 persons per $\mathrm{km} 2$, which makes Benue State the 9th most populous State in Nigeria. Population distribution between male and females in Benue is almost equal (with 50.4\% male and 49.6\% female) (Nigeria Data Portal 2006). The state capital (Makurdi has a population density of over 380 person per $\mathrm{km}^{2}$ while Vandeikya, Okpokwu, Ogbdibo, Obi, Gboko have between 160 and 200 inhabitant per $\mathrm{km}^{2}$. Some other areas like Guma, Gwer East, Ohimini, Katsina-Ala, Apa, Logo, and Agatu have just about 70 persons per $\mathrm{km}^{2}$, thus leaving a vast expanse of land for agriculture (Ajaero 2007). The distribution of the population according to the local government areas varies considerably, and Tiv remains the far dominant ethnic group followed by the Idoma. The predominant inhabitant of the State, including Tiv, Idoma, and the Igede people speak Tiv, Idoma, and Igede languages, respectively (Ajaero 2007). Other tribes include the Abakpa, Jukun, Hausa, Igbo, Akweya and the Nyifon. The dominant Tiv ethnic group occupies fourteen of the 23 local governments area together with the Etulo and the Jekun leaving the remaining nine local government areas to the Idoma, Igede, Igbo, Akweya and the Nyifon (Ajaero 2007).

Benue state shares boundaries with five other states, namely, Nasarawa state to the North, Taraba state to the east, Cross River state to the south-east, Enugu state to the southwest, and Kogi state to the west. The Southern part of the state shares boundary with the Republic of Cameroon. The State is also bordered on the North by $280 \mathrm{~km}$ River Benue and traversed by $202 \mathrm{~km}$ of River Katsina-Ala in the inland areas.

Agriculture is the backbone of Benue State's economy, and the State is the primary source of food in Nigeria acclaiming the slogan 'the food basket of the nation.' Benue state is endowed with fertile arable land and abundant raw materials and human resources with about $80 \%$ of the population directly involved in agriculture (Akaakohol and Aye 2014). Based on its unique location, climatic condition, fertile land, and resources, the State is believed to have the highest opportunity for agricultural investment than any other state in Nigeria. Benue state manifests two major seasons, the rainy season from around April to October and the dry season from November to March. Chili pepper is usually cultivated during the raining season in Benue State. Annual average rainfall varies from $1750 \mathrm{~mm}$ in the Southern part of the State to $1250 \mathrm{~mm}$ in the North (Nwalem et al. 2016. Farming activities are majorly carried out by small-scale farmers who often don't get optimal economic returns on what they produce. This is because of bad road networks, poor storage facilities, lack of proper processing techniques, inadequate government policies, natural disasters like drought, flood, and global warming (Akaakohol and Aye 2014) (Figs. 1, 2).

Population, sampling procedure and data collection

Participants in this study are those who are involved in the production and sale of chili pepper. They are all marketers operating at different levels of marketing in the business. These include producers, processors, processed retailers, and non-processed retailers operating at a small-scale level. Producers are those who are primarily involved in farming chili to sell their produce in the raw (unprocessed) form. Non-processed retailers are those who buy the chili from producers and sell without processing it into any form. Processors are those involved in converting the raw chili pepper into different kinds of finished products such as powdered chili, chili source, etc. 


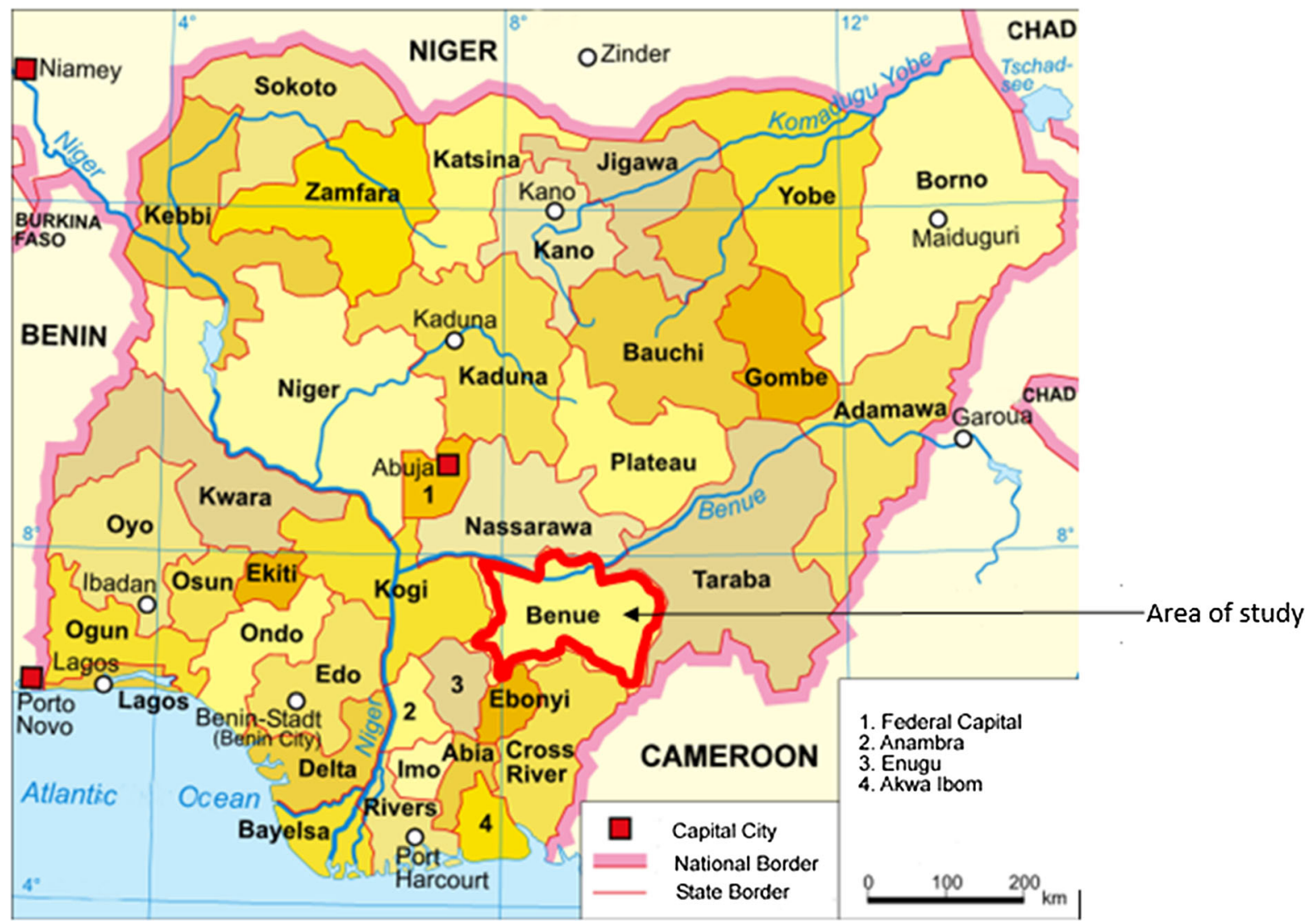

Fig. 1 Map of Nigeria showing the location of Benue State

before selling to consumers. Meanwhile, processed retailers are those who buy chili that has been transformed into different types of finished products by the processors and then sells to consumers. Primary data were collected through a representative household survey over a period of 6 months using structured questionnaires and assisted by agricultural extension workers who served as enumerators. A combination of purposive and random sampling techniques was used to recruits participants. Benue State is divided into three (3) agricultural zones including Zone A, Zone B, and Zone C. Firstly, two local government areas each were purposely selected from Zone A and Zone B while three local government areas were purposely selected from zone $\mathrm{C}$. The selection of local government areas was based on the amount of chili produced per day. Local governments with the highest chili pepper production were selected first. Following Ekhuemelo (2015), the average quantity of chili pepper produced per zone in Benue State is as follows: Zone A produces 2.33 tones per hectares, Zone B 2.35 tones per hectares and Zone C 3.2 tones per hectares. To avoid sampling bias and to ensure high representation of marketers in our selection, two local government areas were selected in Zone A and B because they are made up of seven local governments while three local government areas were selected in Zone $\mathrm{C}$ because it is made up of nine local government areas. Kwande and Logo Local Government Areas were purposively selected from Zone A. Meanwhile, Guma, and Tarka Local Government Areas were chosen from Zone B. In Zone C, Oju, Obi, and Ohimini Local Government Areas were selected. Marketers were then randomly selected using a $0.2 \%$ sampling proportion because of the variation in the number of marketers in the different local government areas. With the sampling proportion of $0.2 \%, 349$ producers, 152 processors, 143 processed retailers, and 145 non-processed retailers were involved in the study. This gives a 


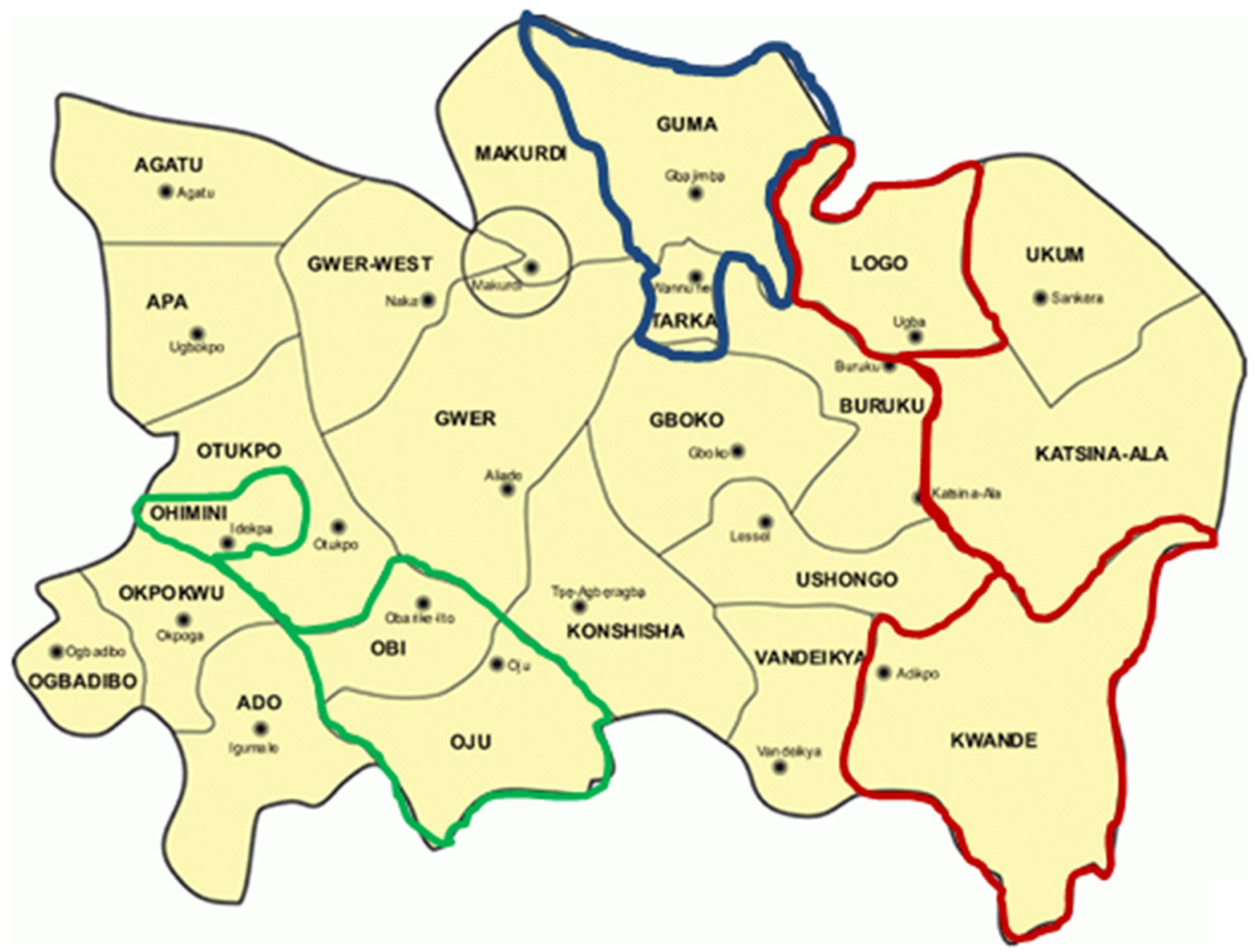

\begin{tabular}{|l|l|}
\hline Key & \multicolumn{1}{|l}{} \\
\hline Studied zones & Local Governments Areas selected in each zone \\
\hline Zone A & Kwande and Logo \\
\hline Zone B & Guma and Tarka \\
\hline Zone C & Oiu, Obi and Ohimini \\
\hline
\end{tabular}

Fig. 2 The map of Benue State and the 23 Local Government Areas showing local governments and the research (Map is Adopted from Convafresh, 2019 https://convafresh.com/map-of-benue-state-its-lgas-local-government-areas/)

total sample size of 789 randomly selected small chili pepper marketers (Table 1).

Model specification

Profit efficiency model

Following Oladeebo and Oluwaranti (2012), the Cobb-Douglas stochastic frontier model can be stated as:

$$
\begin{aligned}
\operatorname{LnY}= & \beta_{0}+\beta_{1} \operatorname{LnX}_{1}+\beta_{2} \operatorname{LnX}_{2}+\beta_{3} \operatorname{LnX}_{3} \\
& +\beta_{4} \operatorname{LnX}_{4}+\mathrm{V}_{1}-\mathrm{U}_{1}
\end{aligned}
$$

where $\mathrm{Ln}=$ Natural logarithm to base $10, \mathrm{Y}=$ Profit (\#), $\beta \mathrm{s}=$ The parameters to be estimated, $X_{1}=$ cost of transportation ( Taxes (\#), $\mathrm{X}_{4}=$ Selling price (\#), $\mathrm{V}_{1}=$ Random errors which are assumed to be independently and identically distributed, $\mathrm{U}_{1}=$ Non negative random variable associated with profit inefficiency. 
Table 1 Sampling selection plan Source: Field survey data, 2018

\begin{tabular}{|c|c|c|c|c|c|c|c|c|c|}
\hline Zones & $\begin{array}{l}\text { Local government } \\
\text { areas }\end{array}$ & Producers & $0.2 \%$ & Processors & $0.2 \%$ & $\begin{array}{l}\text { Processed } \\
\text { retailers }\end{array}$ & $0.2 \%$ & $\begin{array}{l}\text { Non processed } \\
\text { retailers }\end{array}$ & $0.2 \%$ \\
\hline \multirow[t]{2}{*}{ A } & Kwande & 217 & 43 & 83 & 16 & 71 & 14 & 85 & 17 \\
\hline & Logo & 195 & 39 & 70 & 14 & ‘58 & 12 & 74 & 15 \\
\hline Sub total & 2 & 412 & 82 & 153 & 30 & 129 & 26 & 159 & 32 \\
\hline \multirow[t]{2}{*}{ B } & Guma & 211 & 42 & 92 & 19 & 87 & 17 & 91 & 18 \\
\hline & Tarka & 239 & 48 & 108 & 22 & 90 & 18 & 97 & 19 \\
\hline Sub total & 2 & 450 & 90 & 200 & 41 & 177 & 35 & 188 & 37 \\
\hline \multirow[t]{2}{*}{ C } & Oju & 305 & 61 & 153 & 31 & 165 & 33 & 147 & 29 \\
\hline & Obi & 293 & 59 & 132 & 27 & 137 & 27 & 134 & 27 \\
\hline Ushongo & Ohimini & 285 & 57 & 115 & 23 & 112 & 22 & 102 & 20 \\
\hline Sub total & 3 & 883 & 177 & 400 & 81 & 414 & 82 & 383 & 76 \\
\hline Total & 7 & 1745 & 349 & 753 & 152 & 720 & 143 & 730 & 145 \\
\hline $\begin{array}{l}\text { Sample } \\
\text { size }\end{array}$ & & & 349 & & 152 & & 143 & & 145 \\
\hline
\end{tabular}

This is assumed to be independently distributed such that $U_{1}$ is obtained by truncation (at zero) of the normal distribution with variance $\delta^{2}$ and mean $U_{1}$.

The inefficiency of production was modelled in terms of factors such as

$$
\begin{aligned}
\mathrm{U}_{1}= & \sigma_{0}+\sigma_{1} \mathrm{Z}_{1}+\sigma_{2} \mathrm{Z}_{2}+\sigma_{3} \mathrm{Z}_{3}+\sigma_{4} \mathrm{Z}_{4} \\
& +\sigma_{5} \mathrm{Z}_{5}+\sigma_{6} \mathrm{Z}_{6}+\sigma_{7} \mathrm{Z}_{7}+\sigma_{8} \mathrm{Z}_{8}
\end{aligned}
$$

where $\sigma=\mathrm{a}$ vector of unknown parameters to be estimated. $Z_{1}=$ Age (year), $Z_{2}=$ Experience (year), $Z_{3}$ $=$ Credit use ( $\left(Z_{4}=\right.$ Level of Education measured in number of years spent in formal education, $Z_{5}=$ Distance to market $(\mathrm{km}), \mathrm{Z}_{6}=$ Rainfall variability (Very Low $=1$; Low $=2$; Moderate $=3$ and High $=4$ ), $\mathrm{Z}_{7}=$ Temperature variability (Very Low $=1$; Low $=2$; Moderate $=3$ and High $=4$ ), $\mathrm{Z}_{8}=$ Drought (Very Low $=$ 1; Low $=2$; Moderate $=3$ and High $=4$ ).

The estimated coefficient of the inefficiency function provides some explanation for the relative profit efficiency levels among individual chili pepper marketers. Since the dependent variable of the function represents inefficiency for the factors such as age, experience, education, credit use, distance to market, excessive temperature, excessive rainfall and drought, a positive sign of estimated parameter implies that the associated variable has a negative effect on profit efficiency and vice versa.

\section{Results and discussion}

Factors affecting profit efficiency of chili pepper marketers presented in Table 2 was analyzed using stochastic profit function model. The result showed that sigma square was significant for all the marketers indicating the goodness of fit of the model. Gamma was also significant indicating that $27 \%, 31 \%, 59 \%$ and $35 \%$ of the variation of small-scale chili pepper marketers' profit was due to profit inefficiency. The result further showed that: for producer and marketers the coefficient of selling price (2.3) was positive and significant at $1 \%$ level indicating that a unit increase in selling price increase profit of producer and marketers by $2.3 \%$. This could be due to price volatility of agricultural commodities which is paramount for profitability in agribusiness. This result is in line with the findings of Wongnaa et al. (2014) that an increase in the selling price of tomatoes is associated with an increase in the profit of tomato marketers in the Ashanti Region of Ghana. However, the coefficients of cost of transportation, cost of offloading, and taxes were not significant; thus, had no significant effect on the profit of producer and marketers. As for processors, the coefficient of cost of transportation $(-2.17)$ and taxes $(-1.15)$ was negative and significant at 1 and $5 \%$ level respectively indicating that a unit increase in the cost of transportation and the taxes decrease profit by 
Table 2 Determinants of profit efficiency among small scale chili pepper marketers

\begin{tabular}{|c|c|c|c|c|}
\hline Variables & $\begin{array}{l}\text { Producer and marketers } \\
\text { Coefficients }\end{array}$ & $\begin{array}{l}\text { Processors } \\
\text { Coefficients }\end{array}$ & $\begin{array}{l}\text { Processed retailers } \\
\text { Coefficients }\end{array}$ & $\begin{array}{l}\text { Non processed retailers } \\
\text { Coefficients }\end{array}$ \\
\hline Cost of transportation & $1.8(0.55)$ & $-2.17(2.6)$ & $-1.9(1.97)^{* *}$ & $1.2(0.99)$ \\
\hline Cost of offloading & $0.32(1.45)$ & $1.65(0.23)$ & $0.06(1.06)$ & $0.25(1.48)$ \\
\hline Taxes & $0.61(0.39)$ & $-1.45(2.35)^{* *}$ & $0.53(1.3)$ & $-0.45(2.18)^{* *}$ \\
\hline Selling price & $2.3(2.75)^{* * *}$ & $1.62(0.6)$ & $0.45(1.22)$ & $1.64(0.69)$ \\
\hline Constant & $4.5(2.69) * * *$ & $6.8(3.35)^{* * *}$ & $1.06(3.15)^{* * *}$ & $2.98(2.6) * * *$ \\
\hline \multicolumn{5}{|l|}{ Inefficiency model } \\
\hline Constant & $1.18(2.2)^{* *}$ & $1.96(3.32)^{* * *}$ & $1.7(2.25)^{* *}$ & $1.11(1.45)$ \\
\hline Age & $0.52(0.9)$ & $1.21(0.31)$ & $0.67(2.12)^{* *}$ & $0.67(1.2)$ \\
\hline Experience & $0.23(1.45)$ & $0.02(1.2)$ & $0.4(1.99)^{* *}$ & $0.53(0.83)$ \\
\hline Credit use & $0.45(.53)$ & $-0.67(1.98)^{* *}$ & $0.23(0.05)$ & $1.2(0.75)$ \\
\hline Education & $2.1(1.34)$ & $-1.21(2.3)^{* *}$ & $0.4(0.6)$ & $0.97(2.1)^{* *}$ \\
\hline Distance to market & $-1.2(2.6)^{* * *}$ & $0.6(0.85)$ & $0.8(0.09)$ & $0.33(1.23)$ \\
\hline Temperature variability & $0.21(0.98)$ & $-0.32(1.98)^{* *}$ & $-0.27(2.05)^{* *}$ & $0.17(1.07)$ \\
\hline Rainfall variability & $0.15(2.34)^{* *}$ & $0.05(0.97)$ & $1.7(1.47)$ & $1.34(2.49) * *$ \\
\hline Drought & $1.23(2.22)^{* *}$ & $0.67(0.86)$ & $0.59(1.13)$ & $0.56(1.54)$ \\
\hline Sigma square & $0.32(3.23)^{* * *}$ & $0.52(4.22) * * *$ & $0.71(6.24) * * *$ & $0.35(2.35)^{* *}$ \\
\hline Gamma & $0.27(2.79) * * *$ & $0.31(3.44) * * *$ & $0.59(4.33) * * *$ & $0.28(1.98)^{* *}$ \\
\hline Likelihood ratio & 29 & 39 & 44 & 30 \\
\hline
\end{tabular}

$* * *, * *$ Significance at $1 \%$ and $5 \%$ respectively. Values in brackets are $\mathrm{t}$ statistics

2.17 and $1.15 \%$ respectively. This result is in line with the findings of Salau and Salman (2017), who found that an increase in the cost of transportation will reduce the profit of tomato marketers in Ilorin, Nigeria. For processed retailers, the coefficient of the cost of transportation (-1.9) was negative and significant at $5 \%$, indicating that a unit increase in the cost of transportation reduces profit by $1.9 \%$. This result is in line with findings of Tamene and Magento (2017) who found a negative correlation between productivity and cost of transportation in Horro Guduru Wollega Zone, Western Ethiopia. However, the coefficient of the cost of offloading, taxes, and selling price was not significant; thus, it did not affect the profit of processed retailers. For non-processed retailers, the coefficient of taxes $(-0.45)$ was negative and significant at 5\% level indicating that a unit increase in taxes will decrease the profit of nonprocessed retailers by $0.45 \%$. This finding is in line with Djomo (2019) who found that an increase in tax reduces profit of young males and females' rice and maize producer and marketers in Cameroon.
For producer and marketers, the result of the factors affecting profit efficiency shows that the coefficient of distance to market $(-1.2)$ was negative and significant at $1 \%$ level indicating that unit increase in distance to market increases profit efficiency of producer and marketers. This result is in line with findings of Bocher and Simtowe (2016) who found that increases in the distance to market will reduce the profitability of groundnut farmers in Malawi. In contrast, the coefficients for rainfall variability (0.15) and drought (1.23) were positive and significant at 5\% level indicating that a unit increase in rainfall and drought will decrease profit efficiency of producers and marketers of chili pepper in the study area. This could be explained by the fact that chili pepper is perishable by nature which is usually affected by climatic variations. This could also be explained by the fact that during the rainy season, most crops are facing issues such as flower abortions, unusual flowering and fruiting time, including low yields due to the effects of climate change (Mohammed and Hassan 2018). Also, droughts harm the agricultural productivity capacity 
in Nigeria, as pointed by the Food and Agriculture Organization (FAO) in their study on climate smartagriculture in Adamawa State, Nigeria (FAO 2019). However, the coefficients of age, experience, credit use, education, and temperature variability were not significant; therefore, have no significant effect on profit efficiency. For the processors, the coefficients of credit use $(-0.67)$, education $(-1.21)$, and temperature variability $(-0.32)$ were negative and significant at $5 \%$, indicating that credit use, education, and high temperature increases profit efficiency of processors. This could be due to the fact that efficient utilization of credit can serve as a boost to profit as well as education provides adequate knowledge for agribusiness management. However, the coefficients of age, experience, credit use, education, and temperature variability were not significant; therefore, have no significant effect on profit efficiency. For the processors, the coefficients of credit use $(-0.67)$, education $(-1.21)$, and temperature variability $(-0.32)$ were negative and significant at $5 \%$, indicating that credit use, education, and high temperature increases profit efficiency of processors. This could be because efficient utilization of credit can serve as a boost to profit as well as education provides adequate knowledge for agribusiness management. However, the coefficients of age, distance to market, excessive rainfall, and drought were not significant; thus, they had no significant effect on the profit efficiency of processors. For processed retailers, the coefficients of age (0.67) and experience (0.4) were positive and significant at $5 \%$ level. This result implies that age and experience decrease the profit efficiency for processed retailers. This could be because aging and experienced marketers assume to have control on their businesses throughout the season and this will negatively affect their businesses. This result is in contrast to the findings of Mussa et al. (2012), who found a negative relationship between age, experience, and profit efficiency of smallholder mixed crop-livestock agricultural systems in Ethiopia. In contrast, the coefficient of temperature variability $(-0.27)$ was negative and significant at $5 \%$ level, indicating that an increase in temperature will increase profit efficiency. This could be due to the fact that the temperature is paramount to preserving processed chili pepper. This result confirms with Mariara (2006) findings that an increase in winter temperatures is associated with higher crop revenue in Kenya. However, the coefficients of credit use, education, and distance to market, excessive rainfall, and drought were not significant. Therefore, have no significant effect on profit efficiency among processed chili pepper retailers. Finally, for nonprocessed retailers, the coefficients of education (0.97) and rainfall variability (1.34) were positive and significant at $5 \%$ level, indicating that education and rainfall decrease profit efficiency of non-processed retailers. This could be due to the fact that chili pepper is perishable by nature and it is usually affected by rainfall variability. This result agrees with Molua and Lambi (2006) found that a 4.5 percent increase in precipitation in the absence of irrigation facilities would be detrimental to Cameroon's agriculture, leading to a loss of almost 46.7 percent in output value. Also, educated marketers assume to have control over their businesses, given their academic knowledge, which may likely affect their perception of the business cycle of chili pepper. This result disagrees with Oladeebo and Oluwaranti (2012), who found that education influences efficiency either in quality or quantity. It also improves the level of technological adoption, which would likely increase efficiency.

The result of profit efficiency estimates is presented in Table 3. From the table, producers and marketer's profit efficiency ranges between 0.34 and 0.75 with an average of 0.54 . For processors, profit efficiency ranges between 0.41 and 0.83 with average of 0.75. Profit efficiency estimates for processed retailers range from 0.48 to 0.89 with an average of 0.86. Finally, for non-processed retailers, profit efficiency estimates range between 0.39 and 0.75 with a mean of 0.67 . These results show that profit efficiency estimates could be increased by $46 \%, 25 \%$, $14 \%$ and $33 \%$ for producer, marketers, processors, processed retailers, and non-processed retailers if the available resources are efficiently utilized. The results for the producer and marketers, processors and nonprocessed retailers are lower than the value found by Ojo et al. (2009) who found an average profit efficiency of 0.77 for cowpea farmers in Nigeria and the result for processed retailers is higher than the value found by Nguyen (2017) who found an average profit efficiency of 0.77 for rice farmers in Vietnam. 
Table 3 Profit efficiency estimates

\begin{tabular}{|c|c|c|c|c|c|c|c|c|}
\hline \multirow[t]{2}{*}{ Profit efficiency estimates } & \multicolumn{2}{|c|}{ Producer and marketers } & \multicolumn{2}{|l|}{ Processors } & \multicolumn{2}{|c|}{ Processed retailers } & \multicolumn{2}{|c|}{ Non processed retailers } \\
\hline & Frequency & Percentage & Frequency & Percentage & Frequency & Percentage & Frequency & Percentage \\
\hline $0.3-0.5$ & 77 & 22 & 20 & 13 & 17 & 12 & 22 & 15 \\
\hline $0.31-0.7$ & 181 & 52 & 23 & 15 & 30 & 21 & 91 & 63 \\
\hline$\geq 0.72$ & 91 & 26 & 109 & 72 & 96 & 67 & 32 & 22 \\
\hline Total & 349 & 100 & 152 & 100 & 143 & 100 & 145 & 100 \\
\hline Mean & 0.54 & & 0.75 & & 0.86 & & 0.67 & \\
\hline Maximum & 0.75 & & 0.83 & & 0.89 & & 0.75 & \\
\hline Minimum & 0.34 & & 0.41 & & 0.48 & & 0.39 & \\
\hline
\end{tabular}

\section{Conclusion and recommendations}

This study analyzed profit efficiency among small scale chili pepper marketers in Benue State, Nigeria. The results show that chili pepper marketers (producers, processors, processed retailers, and nonprocessed retailers) perceived that rainfall variability, temperature variability, and drought significantly affect their profit efficiency. Further, on average, small scale chili pepper marketers are relatively profit efficient. Also, the results showed that in the marketing chain, small scale processed retailers had the highest mean profit efficiency. It is therefore recommended that:

1. Switching business to adapted crop varieties (cereal crops) that are more resilient to climate change could be an opportunity to small scale chili pepper marketers struggling with chili pepper to leapfrog past performance and become more productive.

2. Training on the preservation of perishable crops should be given to chili pepper producers and marketers and non-processed retailers, given that the variability in rainfall decreases their profit efficiency.

3. Given that the cost of transportation reduces marketing profit, federal and state roads should be reconstructed and rehabilitated to facilitate the transport of agricultural raw materials and products.

4. Price control should be instituted to protect small scale chili pepper marketers due to the volatile nature of the price of agricultural commodities. Given that at each level of the marketing chain, there is profit, small scale chili pepper marketers should be empowered to invest in the entire marketing chain.

Acknowledgements Open access funding provided by University of Gothenburg.

Funding This research received no specific grant from any funding agency, commercial or not-for-profit organization.

\section{Compliance with ethical standards}

Conflicts of interest All author declares that they have no conflict of interest.

Ethical standard We, the authors state that paper "the perceived effects of climate change on profit efficiency among small scale chili pepper marketers in Benue State, Nigeria" complies with ethical standards for the social sciences.

Open Access This article is licensed under a Creative Commons Attribution 4.0 International License, which permits use, sharing, adaptation, distribution and reproduction in any medium or format, as long as you give appropriate credit to the original author(s) and the source, provide a link to the Creative Commons licence, and indicate if changes were made. The images or other third party material in this article are included in the article's Creative Commons licence, unless indicated otherwise in a credit line to the material. If material is not included in the article's Creative Commons licence and your intended use is not permitted by statutory regulation or exceeds the permitted use, you will need to obtain permission directly from the copyright holder. To view a copy of this licence, visit http://creativecommons.org/licenses/by/4.0/. 


\section{References}

Adefolalu, D. (2007). Climate change and economic sustainability in Nigeria. Paper presented at the International conference on climate change. Nnamdi Azikiwe University, Awka 12-14 June 2007.

Adesina, A. A., \& Djato, K. K. (1996). Relative efficiency of women as farm managers: Profit function analysis in Cote d'Ivoire. Agricultural Economics, 16(1), 47-53.

Aiello, F., \& Bonanno, G. (2013). Profit and cost efficiency in the Italian banking industry (2006-2011). Economics and Business Letters, 2(4), 190-205.

Aigner, D., Lovell, C. A. K., \& Schmidt, P. (1977). Formulation and estimation of stochastic frontier production function models. Journal of Econometrics, 6(1), 21-37.

Ajaero, C. (2007). A brand new image for Benue. Newswatch Mag. Available at https://www.wikizero.com/en/Benue_ State.

Akaakohol, M. A., \& Aye, G. C. (2014). Diversification and farm household welfare in Makurdi, Benue State, Nigeria. Development Studies Research. An Open Access Journal, 1 (1), 168-175.

Akpotor, A. S., \& Agbebaku, P. E. (2010). The United Nations reforms and Nigeria's quest for a permanent seat. Journal of Social Sciences, 24(1), 51-55.

Alexandratos, N., \& Bruinsma, J. (2012). World agriculture towards 2030/2050: The 2012 revision. Food and Agriculture Organization of the United Nations, ESA Working Paper No. 12-03.

Ali, M., \& Flinn, J. C. (1989). Profit efficiency among basmati rice producers in Pakistan Punjab. American Journal of Agricultural Economics, 71(2), 303-310.

Aliyu, L., Yahaya, R. A., Arunah, U. L., \& Haruna, I. M. (2012). Response of two chilli pepper varieties (Capsicum frutescens L.) to harvesting frequency. Elixir International Journal, 42(2012), 6493-6495.

Aloni, B., Pressman, E., \& Karni, L. (1999). The effects of fruit load, defoliation and night temperature on the morphology of pepper flowers and on fruit shape. Annals of Botany, 83 (5), 529-534.

Asogwa B. C., Umeh J. C., \& Ater P. I. (2006). Technical efficiency analysis of Nigerian cassava farmers. A guide for food security policy. Poster paper prepared for presentation at the international association of agricultural economists conference, Gold Coast, Australia, p. 14.

Avnery, S., Mauzerall, D. L., Liu, J., \& Horowitz, L. W. (2011). Global crop yield reductions due to surface ozone exposure: 1. Year 2000 crop production losses and economic damage. Atmospheric Environment, 45(13), 22842296

Awe, A. A., \& Ajayi, S. O. (2009). Diversification of Nigerian revenue base for economic development: The contribution of the non-oil sector. Pakistan Journal of Social Sciences, $6(3), 138-143$.

Ayyogari, K., Sidhya, P., \& Pandit, M. K. (2014). Impact of climate change on vegetable in cultivation: A Review. International Journal of Agriculture, Environment and Biotechnology (IJAEB), 7(1), 145-155.

Bala, M. (2015). Analysis of resource use efficiency and profitability in chilli pepper (Capsicum Frutescens) production and its contribution to household farm income in Kaduna State. A Thesis Submitted to the School of Postgraduate Studies, Ahmadu Bello University, Zaria, in Partial Fulfillment of the Requirements for the award of Master of Science Degree in Agricultural Economics, 92 p.

Barrueto, A. K., Merz, J., Clot, N., \& Hammer, T. (2017). Climate changes and their impact on agricultural market systems: Examples from Nepal. Sustainability, 9(2207), $1-16$.

Battese, G. E., \& Coelli, T. J. (1995). A model for technical inefficiency effects in a stochastic frontier production function for panel data. Empirical Economics, 20(2), 325332.

Berkhout, F., Hertin, J., \& Jordan, A. (2002). Socio-economic futures in climate change impact assessment: Using scenarios as 'learning machines'. Global Environmental Change, 12(2), 83-95.

Bhutia, K. L., Khanna, V. K., Tombisana, M. N. G., \& Nangsol, B. D. (2018). Effects of climate change on growth and development of chilli. Agrotechnology, 7(2), $1-4$.

Bocher, T., \& Simtowe, F. (2016). Are farmers profit efficient? Evidence from Groundnut farmers in Malawi. Invited Poster paper prepared for presentation at the African Association of Agricultural Economists, September 2326, Addis Ababa, Ethiopia.

Bosland, P. W., \& Votava, E. J. (2000). Pepper: Vegetable and spice Capsicum. New York: CABI Publishing.

Djomo, C. R. F. (2019). Gender differentials and profit efficiency among youth entrepreneurs in rice and maize marketing in Cameroon. Report submitted at the international institute of tropical agriculture (IITA) under the project. Youth Researching Youth: Competitive Fellowships for Young African Scholars Researching Youth Engagement in Rural Economic Activities in Africa.

Ekhuemelo, C. (2015). Seed borne fungi of Chilli Pepper (Capsicum frutescens) from pepper producing areas of Benue State, Nigeria. Agriculture and Biology Journal of North America, 4(4), 370-374.

Enete, A. A., \& Amusa, T. A. (2010). Challenges of agricultural adaptation to climate change in Nigeria: A synthesis from the literature. Field actions science reports. The Journal of Field Actions, 4(2), 1-6.

Erickson, A. N., \& Markhart, A. H. (2001). Flower production, fruit set, and physiology of bell pepper during elevated temperature and vapor pressure deficit. The Journal of the American Society for Horticultural Science, 126(6), 697702.

Federal Ministry of Environment. (2004). Abuja. Available at www.nigeria.com.ngcichng.org/ccinfo.php

Food and Agriculture Organization of United Nations (FAO). (2019). Climate-smart agriculture in adamawa state of Nigeria (p. 22). Rome: CSA Country Profiles for Africa Series.

Garruna-Hernandez, R., Orellana, R., Larque-Saavedra, A., \& Canto, A. (2014). Understanding the physiological responses of a tropical crop (Capsicum chinense Jacq) at high temperature. PLoS ONE, 9(11), 1-9.

Greene, W. H. (1993). The econometric approach to efficiency analysis. The measurement of productivity efficiency: 
Techniques and applications (pp. 92-250). New York: Oxford University Press.

Hoang, L. V., \& Yabe, M. (2012). Impact of environmental factors on profit efficiency of rice production: A study in Vietnam's Red River Delta. World Academy of Science, Engineering and Technology International Journal of Agricultural and Biosystems Engineering, 6(6), 330337.

Howard, L. R., Talcott, S. T., Brenes, C. H., \& Villalon, B. (2000). Changes in phytochemical andantioxidant activity of selected pepper cultivars (Capsicum sp.) asinfluenced by maturity. Journal of Agriculture and Food Chemistry, 48(5), 1713-1720.

https://en.wikipedia.org/wiki/Benue_State. Accessed on 23 June 2019

https://population.gov.ng. Accessed on 23 June 2019

Huizinga, H. P., Nelissen, J. H. M., \& Vennet, R. V. (2001). Efficiency effects of Bank Mergers and acquisitions in Europe. Tinbergen institute discussion paper 088/3, p. 41.

Idowu-agida O. O., Nwaguma, E. I. \& Adeoye I. B. (2010). Cost implication of wet and dry season pepper production in Ibadan, Southwestern Nigeria. National Horticultural Research Institute, Ibadan, Nigeria. Agriculture and Biology Journal of North America

Ikhile, C. I. (2007). Impacts of climate variability and change on the hydrology and water resources of the Benin-Owena River Basin. Ph.D. thesis submitted to the Department of Geography and Regional Planning, University of Benin, Benin City, Nigeria, pp. 234-236.

International Panel on Climate Change (IPCC). (2007a). Summary for policymakers. In S. Solomon, D. Qin, M. Manning, M. Marquis, K. Averyt, et al. (Eds.), The physical science basis Contribution of working group I to the fourth assessment report of the Intergovernmental Panel on Climate Change (pp. 2-22). Cambridge: Cambridge University Press.

International Panel on Climate Change (IPCC). (2007b). Impacts, adaptation and vulnerability; contribution of working group ii to the fourth assessment report of the intergovernmental panel on climate change (p. 976). Cambridge: Cambridge University Press.

Karki, R., \& Gurung, A. (2012). An overview of climate change and its impact on agriculture: A review from least developing Country, Nepal. The International Journal of Ecosystem, 2(2), 19-24.

Kolawole, O. (2006). Determinants of profit effciency among small scale rice farmers in Nigeria: A profit function approach. Research Journal of Applied Sciences, 1(3), $116-122$.

Lensink, R., \& Meesters, A. (2012). Institutions and bank performance: A stochastic frontier analysis. Oxford Bulletin of Economics and Statistics, 69, 57.

Lobell, D. B., Burke, M. B., Tebaldi, C., Mastrandrea, M. D., Falcon, W. P., \& Naylor, R. L. (2008). Prioritizing climate adaptation needs for food security in 2030. Science, 319 (5863), 607-610.

Maharjan, K. L., \& Joshi, N. P. 2013. Effect of climate variables on yield of major food-crops in Nepal: A time-series analysis. In: Climate Change, Agriculture and Rural Livelihoods in developing countries. Advances in Asian Human-Environmental Research (pp. 127-137). Tokyo: Springer. https://doi.org/10.1007/978-4-431-54343-5_6.
Mariara, K. J. \& Karanja F.K. (2006). The economic impact of climate change on Kenyan crop agriculture: A Ricardian approach, CEEPA Discussion Paper No. 12. Centre for Environmental Economics and Policy in Africa-CEEPA, University of Pretoria, S.A.

Maudus, J., Pastor, J. M., \& Quesada, J. (2003). Cost and profit efficiency in European banks. Journal of in International Financial Markets, Institutions and Money, 12(1), 33-58.

Meeusen, D., \& van de Broek, J. (1997). Efficiency estimation from Cobb-Douglas production functions with composed error. International Economic Review, 18(2), 435-444.

Mendelsohn, R., Morrison, W., Schlesinger, M. E., \& Andronova, N. G. (2000). Country specific market impacts of climate change. Climate Change, 45, 553-569.

Mohammed, T., \& Hassan, T. H. (2018). The effects of climate change on food crop production in northern Nigeria. https://doi.org/10.5281/zenodo.1464995

Molua, E. L., \& Lambi, C. M. (2006). The economic impact of climate change on agriculture in Cameroon. CEEPA Discussion Paper. Centre for Environmental Economics and Policy in Africa-CEEPA, University of Pretoria, S.A.

Mussa, E. C., Obare, G. A., Bogale, A., \& Simtowe, F. P. (2012). Analysis of resource use efficiency in smallholder mixed crop-livestock agricultural systems: Empirical evidence from the central highlands of Ethiopia. Developing Country Studies, 2(9), 30-40.

Nguyen, H. D. (2017). Determinants of profit efficiency among rice farmers in Kien Giang Province, Vietnam. In Proceedings of the 11th Asia-Pacific conference on global business, economics, finance and business management (AP17Thai Conference). ISBN: 978-1-943579-72-3. Bangkok-Thailand. 16-18 February 2017. Paper ID: T748.

Nigerian Data Portal. (2006). State population. Available from http://nigeria.opendataforafrica.org/ifpbxbd/state-popula tion-2006

Nwalem, M. P. (2015). Relationship between level of adverse effect of perceived dimensions of climate change manifestations and production efficiency among sesame farmers in Benue State, Nigeria. M.Sc. Thesis submitted to the Department of Agricultural Economics. University of Agriculture, Makurdi-Benue State, Nigeria.

Nwalem, M. P., Asogwa, B. C., \& Aye, G. C. (2019). Analysis of climate change manifestations among sesame farmers in Benue State, Nigeria. Journal of Scientific Research and Reports, 22(2), 1-7.

Nwalem, M. P., Ukpe, U. H., Djomo, R. F., \& Dzever, D. (2016). Factors influencing market participation among sesame producers in Benue State, Nigeria. International Journal of Research Studies in Agricultural Sciences (IJRSAS), 2(5), 1-5.

Obioha, E. (2008). Climate Change, population drift and violent conflict over land resources in North Eastern Nigeria. Journal of Human Ecology, 23(4), 311-324.

Ocheni, S. I. (2015). Impact of fuel price increaseon the Nigerian economy. Mediterranean Journal of Social Sciences, 6(1 S1), 560.

Ogundari, K. (2006). Determinants Of profit effciency among small scale rice farmers in Nigeria: A profit function approach. Posterpaper prepared for presentation at the 
International Association of Agricultural Economists Conference, Gold Coast, Australia, August 12-18, 15 p.

Ojo, M. A., Mohammed, U. S., Ojo, A. O., Yisa, E. S., \& Tsado, J. H. (2009). Profit efficiency of small scale cowpea farmers in Niger State, Nigeria. International Journal of Agricultural Economics and Rural Development, 2(2), 40-47.

Oladeebo, J. O., \& Oluwaranti, A. S. (2012). Profit efficiency among cassava producers: Empirical evidence from South western Nigeria. Journal of Agricultural Economics and Development, 1(2), 46-52.

Olayemi, F. F., Adegbola, J. A., Bamishaiye, E. I., \& Awagu, E. F. (2012). Assessment of postharvest losses of some selected crops in eight local government areas of rivers state, Nigeria. Asian Journal of Rural Development, 2(1), $13-23$.

Pena, R., \& Hughes, J. (2007). Improving vegetable productivity in a variable and changing climate. SAT E Journal, 4 (1), 1-22.

Rahman, S. (2003). Profit efficiency among Bangladeshi rice farmers. Contributed paper for the 25th conference of the International Association of Agricultural Economists Durban, South Africa, August 2003. P21

Ranjitkar, S., Sujakhu, N. M., Merz, J., Kindt, R., Xu, J., Matin, M. A., Ali, M., \& Zomer, R. J. (2016). Suitability analysis and projected climate change impact on banana and coffee production zones in Nepal. PLoS ONE, 11(9), $1-18$.

Salau, S. A., \& Salman, M. A. (2017). Economic analysis of tomato marketing in Ilorin Metropolis, Kwara State, Nigeria. Journal of Agricultural Sciences, 62(2), 179-190.

Sarada, C., Ratnam, M., Naidu, L. N., Ramana, C. V., \& Rajani, A. (2015). Chilli production and productivity in relation to seasonal weather conditions in Guntur district of Andhra Pradesh. International Journal of Pure and Applied Bioscience, 3(1), 207-213.
Simar, L., \& Wilson, P. W. (2000). A general methodology for bootstrapping in nonparametric frontier models. Journal of Applied Statistics, 27(6), 779-802.

Suleiman, A., \& Isah, S. I. (2010). Spatial integration of selected markets of dried chilli pepper and ginger in Northern Nigeria. Savannah Journal of Agriculture, 5(2), 29-37.

Tamene, S., \& Megento, T. L. (2017). the effect of rural road transport infrastructure on smallholder farmers' agricultural productivity in Horro Guduru Wollega Zone, Western Ethiopia. AUC Geographica, 52(1), 89-99.

Tronga, P. H., \& Napasintuwongb, O. (2015). Profit inefficiency among hybrid rice farmers in Central Vietnam. 1st International conference on asian highland natural resources management, Asia Hi Land. Agriculture and Agricultural Science Procedia, 5(2015), 89-95.

www.cgidd.com. Accessed on 23 July 2019

Wang, H. J., \& Schimdt, P. (2002). One-step and two-step estimation of the effect of exogenous variables on technical efficiency levels. Journal of Productivity Analysis, 18(2), 129-144.

Wiggins, S., Argwings-Kodhek, G., Leavy, J., \& Poulton, C. (2011). Small farm commercialisation in Africa: Reviewing the issues. Research Paper: Future Agricultures Consortium.

Wongnaa, C. A., Mensah, S. O., Ayogyam, A., Asare-Kyire, L., \& Zu-Kwame, S. A. (2014). Economics of tomato marketing in Ashanti Region, Ghana. RJOAS, 2(26), 1-13.

Yanez-Lopez, R., Torres-Pacheco, I., Guevara-Gonzalez, R. G., Hernandez-Zul, M. I., \& Quijano-Carranza, J. A. (2012). The effect of climate change on plant diseases. African Journal of Biotechnology, 11(10), 2417-2428.

Publisher's Note Springer Nature remains neutral with regard to jurisdictional claims in published maps and institutional affiliations. 